\title{
Implementation of Fuzzy Mamdani Method for Traffic Lights Smart City in Rangkasbitung, Lebak Regency, Banten Province (Case Study of the Traffic Light T-junction, Cibadak, By Pas Sukarno Hatta Street) Dentik Karyaningsih ${ }^{1}$, Robby Rizky ${ }^{2 *}$
}

${ }^{1}$ Faculty of Technology and Information at Serang Raya University, Cilegon Street Km. 5, Taman, Drangong, Taktakan, Serang City, Banten 42162

${ }^{2}$ Faculty of Technology and Informatics, Mathla'ul Anwar University, Banten Labuan Street Km. 23, Pandeglang Banten

*Robby_bae87@yahoo.com

\begin{abstract}
Traffic jams are a common sight that can be seen in almost all major cities in Indonesia. One of them is in Rangkasbitung City, Lebak Regency. This happens because the number of vehicles continues to increase. The traffic light control system implemented in Indonesia is a static preset time because the time of each phase is predetermined. This type of control system is still not effective in overcoming traffic congestion, especially at certain peak traffic jams. By using the Mamdani fuzzy logic system, it is possible to implement the human mindset into a system. Some rules can be set out in the fuzzy logic controller. The purpose of this study is to design a traffic light control system using fuzzy inference that regulates traffic based on its density. The data used are observations made at the research site. The conclusion of this study is to explain that the fuzzy mamdani method can solve existing problems in traffic congestion in Rangkasbitung City, Lebak Regency, Banten Province.
\end{abstract}

Keywords: Implementation, Fuzzy Mamdani, traffic, Lebak Regency, Rangkasbitung City

\section{INTRODUCTION}

With the rapid development of technology, especially in the field of motor vehicles, various kinds of vehicle technology were created to facilitate humans in carrying out all kinds of activities. One of the problems that will arise due to the increase in the number of motorized vehicles is traffic congestion due to the undisciplined motorists in traffic. The congestion that arises can be caused by several factors, one of which is the traffic lights that are not good [1]. Traffic is important to increase the movement of the community so that the Government feels it is important to regulate it in accordance with the times, so that the rights of the community to use the streets are maintained. When we discuss Government, each individual in it automatically gives the authorities authority to regulate rights or make rules for individuals with reciprocity in return of rights to each individual. That is an individual obligation as a holder of citizen status [2]. This situation can usually be seen from a crossroads with many queues of vehicles that want to pass a crossroads [3]. The city of Yogyakarta is one of the cities in Indonesia with a very congested level of traffic, one of the reasons is because Yogyakarta is a tourist destination city and has assumed the title of education city so that the population in Yogyakarta is getting higher, means of transportation are much faster than the growth of road infrastructure so that it will add congestion is quite dense [4]. Based on PPRI (Peraturan Pemerintah Republik Indonesia)/Government Regulation of the 
Republic of Indonesia No. 43 of 1993 concerning road infrastructure and traffic article 4 paragraph 5 that information systems related to traffic signs, road markings, traffic signaling devices, as well as road user control and safety devices are needed so that traffic engineering can be carried out effectively and efficiently [5]. Jakarta is the most traffic-stricken city in rank 22 and lack of use of smart transportation systems such as optimization of traffic systems or dynamic lanes. Congestion has caused many things that will occur such as loss of productivity, loss of income from working people, waste of fuel use, increased stress levels [6]. One important tool in managing traffic is a traffic light. Traffic lights that are currently very helpful in the smoothness and regulation of traffic. However, traffic lights can also be one of the causes of traffic jams. This can happen because the current traffic light settings mostly use a fixed time management system where the lights are set to work on a fixed time basis, without regard to the rise in traffic flow [7]. Currently in Indonesia, traffic light control technology continues to be developed in such a way, so that the role of traffic lights is not only to avoid traffic jams but also to improve traffic safety [8]. Traffic accidents are collisions between motorized vehicles (two wheels, four or more) or with other objects on the road. Traffic accidents result in damage to colliding vehicles. The damage caused depends on the severity of the impact and the speed of the vehicle [9]. Adaptive traffic light control system began to be developed to overcome the problem of traffic congestion, has made the concept of adaptive control with two strategies namely adaptive statistics and fuzzy adaptive [10]. One of the intersections in Medan that uses a manual system is the junction of the yellow pitch which consists of four roads i.e. H. Nasution street, Tritura street, Brigjen Hamid street, Traffic jams and delays that occur during peak hours, i.e. $07.00 \mathrm{am}-09.00 \mathrm{am}, 00.30 \mathrm{pm}-1.30 \mathrm{pm}$ and $05.00 \mathrm{pm}-07.00 \mathrm{pm}$ with a queue length of 100 to 200 meters [11]. Distribution of traffic lights delays at the intersection between the Soekarno Hatta Road and the Ibrahim adjie road, or what is known as the intersection of the One Roof Manunggal Administration System, is determined by the Bandung City Transportation Agency. But every day there is often a long traffic jam at the intersection, especially in the morning and evening [12]. a good traffic light control system will automatically adjust to the density of traffic flow on the lane set [13]. By utilizing the fuzzy theory, especially to determine the boundaries of several components that determine the decision making factors, then a decision support system model can be made to determine the fastest route [14]. Now in Indonesia, traffic light control technology continues to be developed in such a way that the role of traffic lights is not only to avoid traffic jams but also has a role in increasing traffic safety [8].

\section{METHOD}

Fuzzy method is a method that can solve vague or unclear problems with very structured and systematic steps. Therefore the fuzzy method is very much interested in the field of research because it has very good steps in the field of research.The fuzzy process in research is the fuzyfication process, this is a separating part with the degree of membership to differentiate the classes specified in the research, then the process of several rule bases to get IF and ELSE logic to be applied into computer programs. The final step in fuzzy defuzyfication is to calculate the results of the research results[1] Smart cities in the current era are experiencing very rapid progress because in the era of 4.0 has a very large competitiveness cities in the regions have developed technology, one of which is technology in the field of traffic traffic.[2]

In this study the data obtained in several ways including : 
1.Field Research. This is done by conducting a direct review of the object of research in order to get data and information about the things that are examined in this case done by observing directly the object being examined.

2.Literature Study. This is done by collecting and studying literature related to the issue to be discussed, so as to strengthen the research reference base as a research base as a theoretical basis in analyzing research data.

3.Documentation. This is obtained from vehicle condition data around the traffic lights.

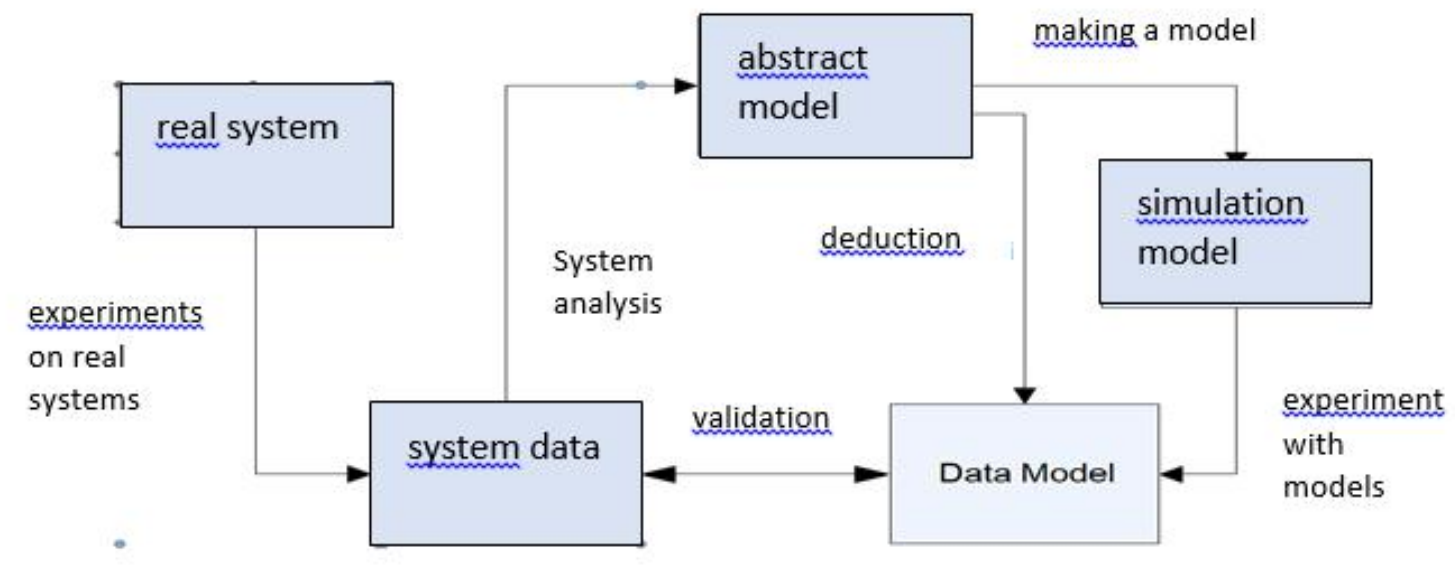

Picture 1. Process Diagram

\section{Caption :}

Real System. All information, observations, and measurement results obtained from the real system (case study on the traffic lights at the intersection of the Cibadak Rangkasbitung area) are collected in a container and referred to as observational data. This observation data describes the actual state of the system obtained empirically.

Data system. This is data taken from the observations at the place of observation and entered into the system to be simulated, this data which illustrates the actual state of traffic conditions at the case study location.

Abstract Model. This is a description of the real system in Lebak based on observational data, then we do an analysis to compile a model that is abstract. To get a statement about the state of the abstract model can be reached in two ways, namely the analytical (deduction) and simulation. 


\section{Jln. By Pass Sukarno Hatta}

Arah jakarta

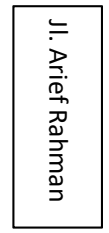

Picture 2. Cibadak Junction, By Pas Soekarno Hatta street

Description of Simulation Models : The simulation model is carried out by creating another real system that is similar to the real system being investigated. Another system that we use for this research is called simulation models. The simulation method has advantages compared to the analytical method, which can be used to investigate models with a high level of complexity, while the analytical method is only used for simple problems.

\section{RESULT}

The traffic light control system at the Cibadak intersection, By pas Sukarno Hatta street, Rangkasbitung which is used today uses a predetermined time allocation. Then displayed in a countdown with the provisions of green lights for 72 seconds, red lights for 40 seconds and yellow lights for 3 seconds. This intersection has four traffic lights that regulate four conditions or lanes including regulating vehicles from the direction of the Mandala terminal towards the Jakarta direction and vice versa, then from the Arief Rahman street of Cibadak towards Jakarta and the mandala terminal. Even though it has four traffic directions, it actually only regulates two traffic conditions. If the lane from the Mandala terminal direction and Jakarta direction the traffic lights turn green then the lane from Arief Rahman street Cibadak to Jakarta or the traffic light mandala terminal turn red. The opposite happened. Vehicle observation is carried out for three times with observation time of 1 hour. The results obtained from observations Monday afternoon were 1256 vehicles from the direction of Jakarta, 1452 vehicles from the direction of the Mandala terminal and 1324 vehicles from the direction of Arief Rahman street Cibadak.

For observations on Saturday afternoon as many as 1335 from the direction of Jakarta, 1782 vehicles from the direction of the mandala terminal, and 1538 vehicles from Arief Rahman Cibadak street. Based on observations on Sunday afternoon, there were 1405 vehicles from Jakarta, 1856 from Mandala terminal, and 1545 vehicles from Arief Rahman Cibadak street. 
Table 1. Fuzzy logic is used in this study

\begin{tabular}{|c|c|c|c|}
\hline Variable & $\begin{array}{c}\text { Fuzzy Association } \\
\text { Name }\end{array}$ & Domain & Unit \\
\hline \multirow{5}{*}{$\begin{array}{l}\text { Num Car Down } \\
\text { (Vehicle queues } \\
\text { from the } \\
\text { direction of } \\
\text { Arief Rahman } \\
\text { Cibadak Street) }\end{array}$} & Very Small & $0 ; 0 ; 10$ & \multirow{5}{*}{ Unit } \\
\hline & Small & $0 ; 10 ; 20$ & \\
\hline & Medium & $10 ; 20 ; 30$ & \\
\hline & Large & $20 ; 30 ; 45$ & \\
\hline & Very Large & $30 ; 45 ; 60 ; 60$ & \\
\hline \multirow{5}{*}{$\begin{array}{l}\text { Red Time } \\
\text { (From Arief } \\
\text { Rahman } \\
\text { Cibadak street) }\end{array}$} & Very Short & $0 ; 0 ; 10$ & \multirow{5}{*}{ seconds } \\
\hline & Short & $0 ; 10 ; 20$ & \\
\hline & Medium & $10 ; 20 ; 30$ & \\
\hline & Long & $20 ; 30 ; 45$ & \\
\hline & Very Long & $30 ; 45 ; 90 ; 90$ & \\
\hline \multirow{3}{*}{ Urgency } & Low & $0 ; 0 ; 1$ & \multirow{3}{*}{-} \\
\hline & Medium & $0 ; 1 ; 2$ & \\
\hline & High & $1 ; 2 ; 3 ; 3$ & \\
\hline \multirow{5}{*}{$\begin{array}{c}\text { Num Car Up } \\
\text { To Jakarta } \\
\text { (Vehicle } \\
\text { Queue) }\end{array}$} & VerySmoll & $0 ; 0 ; 5$ & \multirow{5}{*}{ Unit } \\
\hline & Smoll & $0 ; 5 ; 10$ & \\
\hline & Medium & $5 ; 10 ; 15$ & \\
\hline & Large & $10 ; 15 ; 25$ & \\
\hline & Very Large & $15 ; 25 ; 35 ; 35$ & \\
\hline \multirow{5}{*}{$\begin{array}{l}\text { Red Time (from } \\
\text { directions } \\
\text { Mandala } \\
\text { Terminal) }\end{array}$} & Very Short & $0 ; 0 ; 10$ & \multirow{5}{*}{$\begin{array}{c}\text { secon } \\
\text { ds }\end{array}$} \\
\hline & Short & $0 ; 10 ; 20$ & \\
\hline & Medium & $10 ; 20 ; 30$ & \\
\hline & Long & $20 ; 30 ; 45$ & \\
\hline & Very Long & $30 ; 45 ; 65 ; 65$ & \\
\hline \multirow{3}{*}{ Urgency } & Low & $0 ; 0 ; 1$ & \multirow{3}{*}{ - } \\
\hline & Medium & $0 ; 1 ; 2$ & \\
\hline & High & $1 ; 2 ; 3 ; 3$ & \\
\hline \multirow{5}{*}{$\begin{array}{l}\text { Num Car } \\
\text { Up To } \\
\text { Jakarta } \\
\text { (Vehicle } \\
\text { Queue) }\end{array}$} & Very Small & $0 ; 0 ; 5$ & \multirow{5}{*}{ Unit } \\
\hline & Small & $0 ; 5 ; 10$ & \\
\hline & Medium & $5 ; 10 ; 15$ & \\
\hline & Large & $10 ; 15 ; 25$ & \\
\hline & Very Large & $15 ; 25 ; 35 ; 35$ & \\
\hline \multirow{5}{*}{$\begin{array}{l}\text { RedTime (to } \\
\text { Jakarta) }\end{array}$} & Very Short & $0 ; 0 ; 10$ & \multirow{5}{*}{ seconds } \\
\hline & Short & $0 ; 10 ; 20$ & \\
\hline & Medium & $10 ; 20 ; 30$ & \\
\hline & Long & $20 ; 30 ; 45$ & \\
\hline & Very Long & $30 ; 45 ; 65 ; 65$ & \\
\hline \multirow{3}{*}{ Urgency } & Low & $0 ; 0 ; 1$ & \multirow{3}{*}{ - } \\
\hline & Medium & $0 ; 1 ; 2$ & \\
\hline & High & $1 ; 2 ; 3 ; 3$ & \\
\hline
\end{tabular}




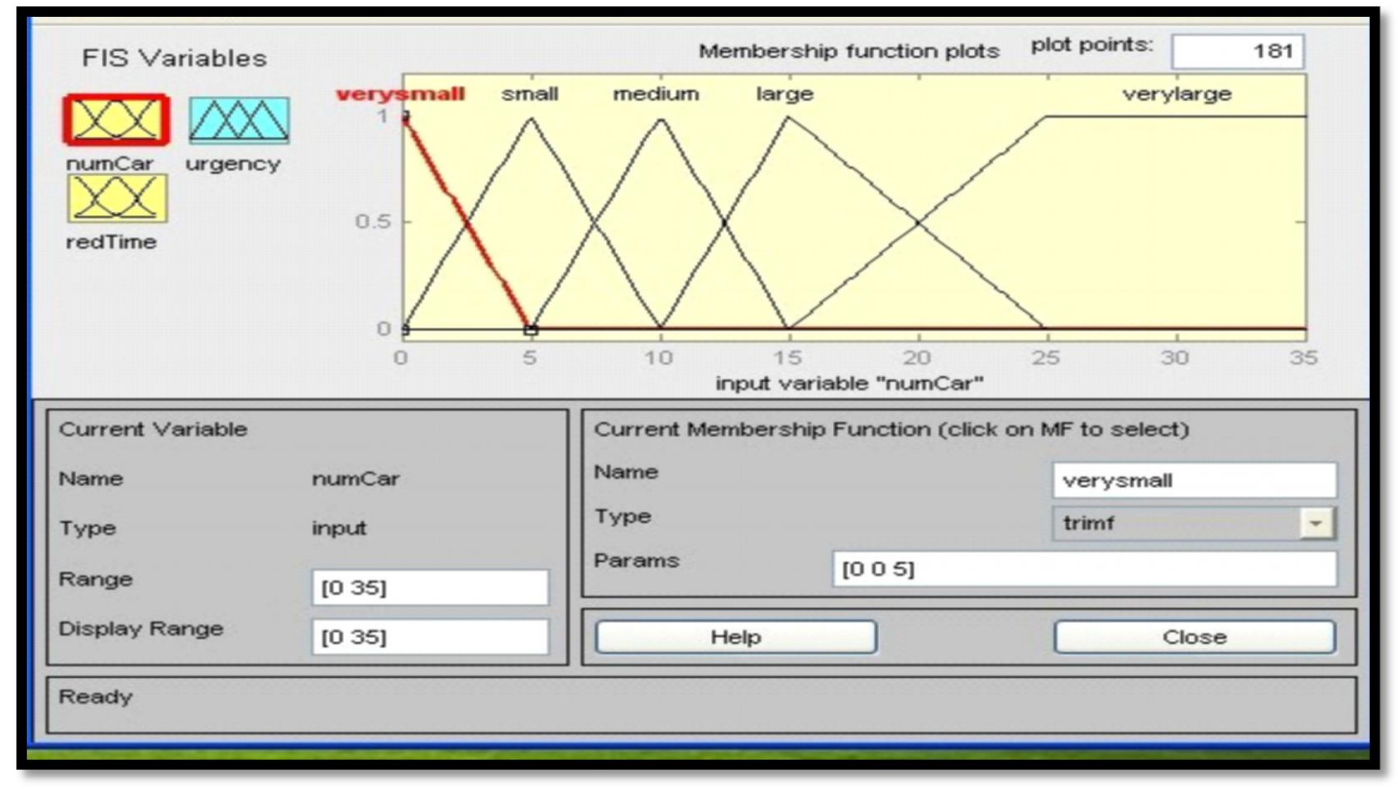

Picture 3. Membership Function from Andala Terminal.

Membership function of variables Queue Vehicle (Muncar) from the bus terminal mandala headed Directions Jakarta and so did the opposite happens at intervals of 0-35

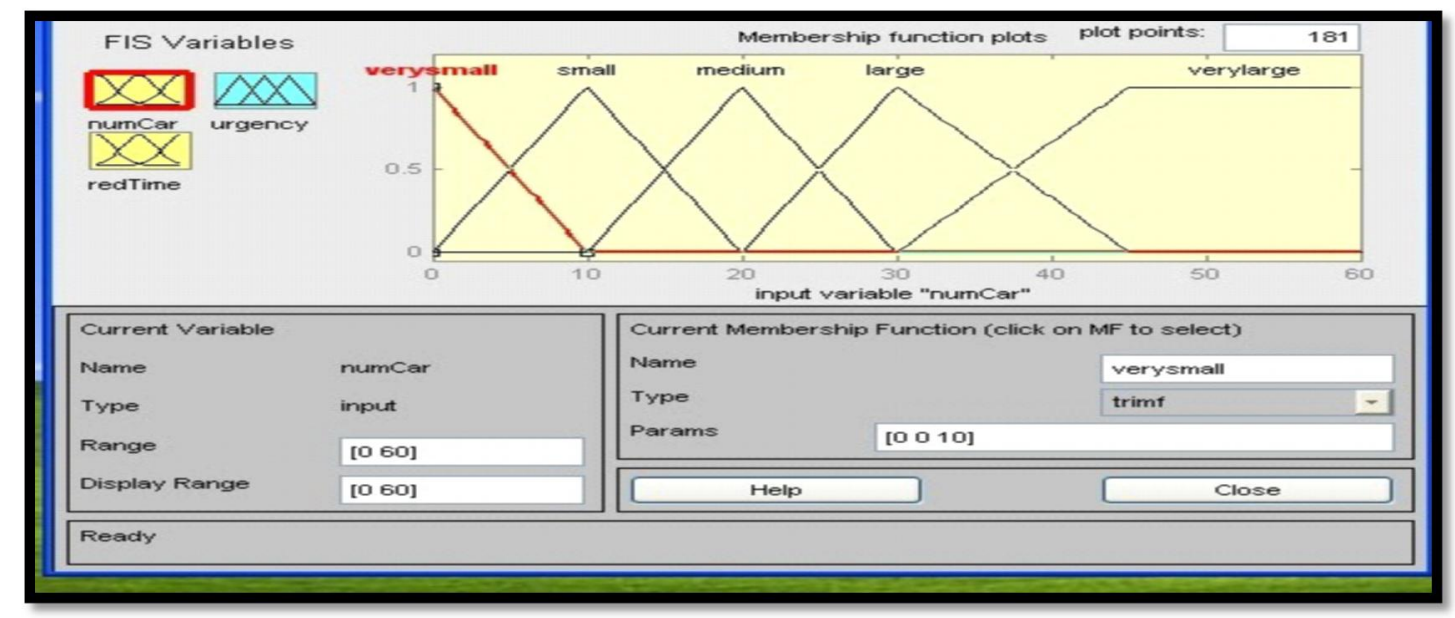

Picture 4. Red Light membership function

The membership function of the red light is on (RedTime) from the direction of the mandala terminal towards the Jakarta Direction, with intervals 0 - 65 


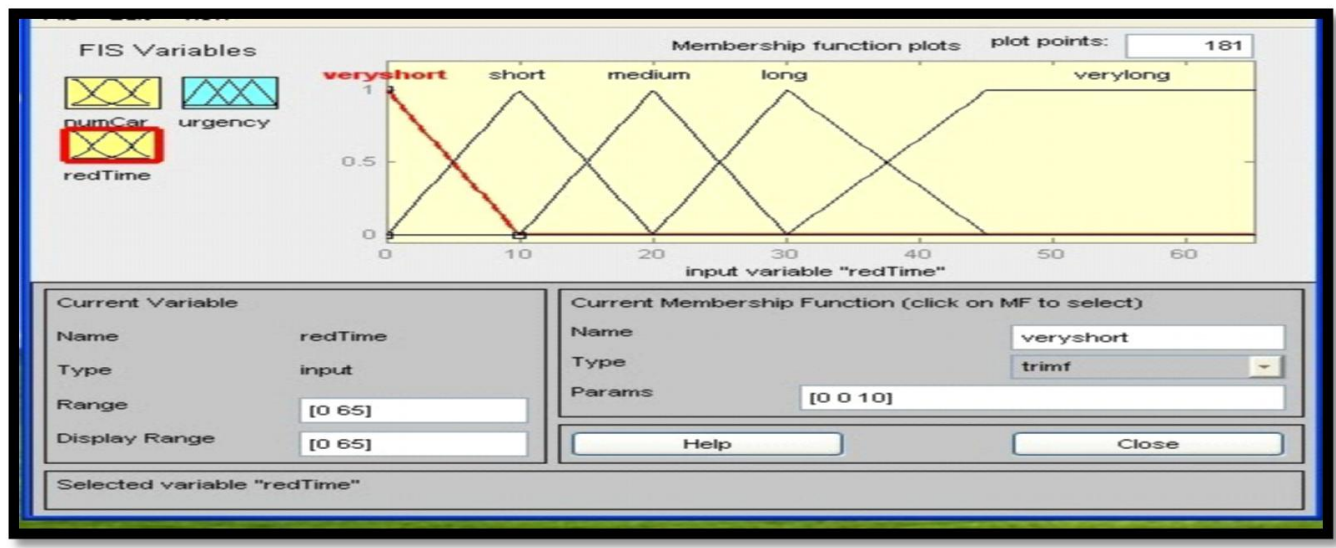

Picture 5. Membership Function from Arif Rahman Cibadak street

The Membership Function of the Vehicle Queue (NumCar) variable from Arief Rahman Cibadak street, with an interval of 0-60

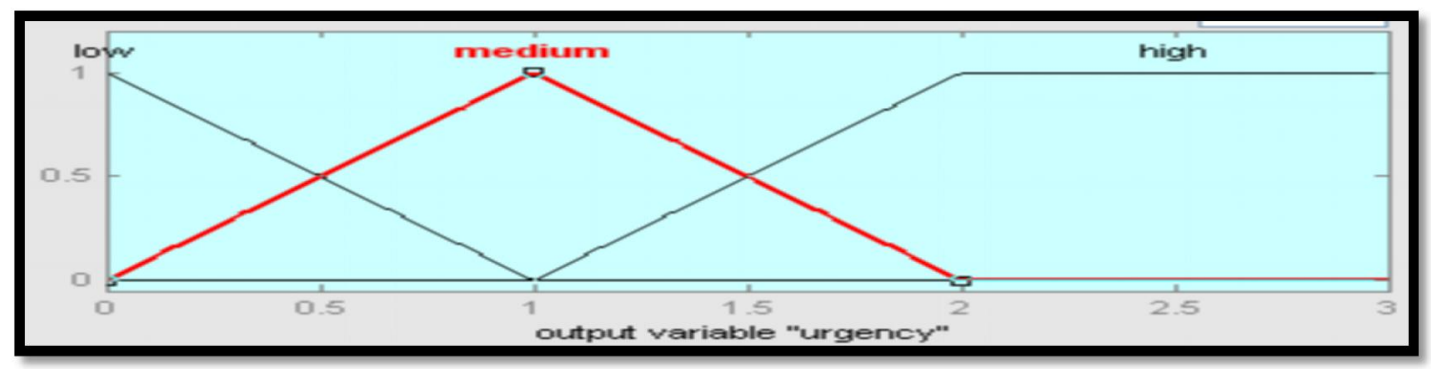

Picture 6.urgency membership function

From these rules it can be seen how much the value of the Urgency (importance) condition can be categorized as low,medium,high

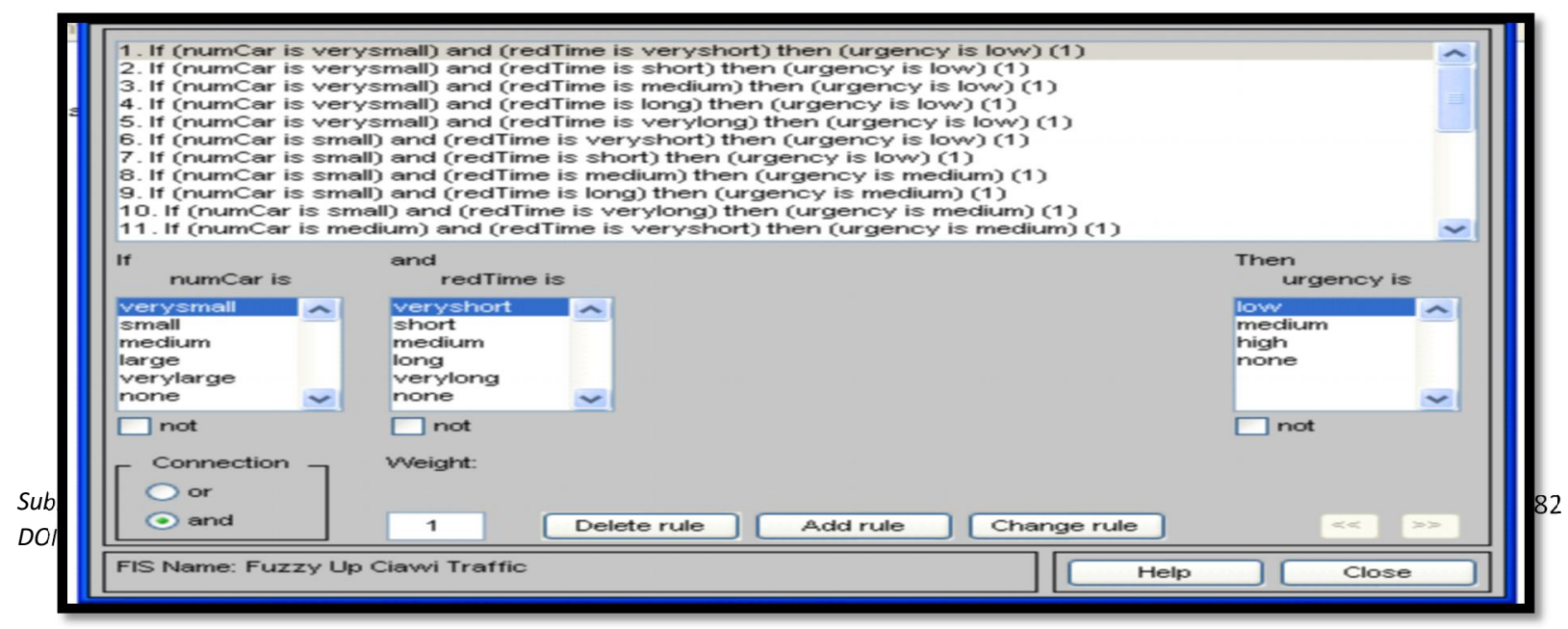


Picture 7. Filled rules editor

\begin{tabular}{cc}
\hline NO & Rule Fuzzy Mamdani \\
\hline 1 & IF numcar is verysmall and red times is very short then urgency is low \\
\hline 2 & IF numcar is verysmall and red times is short then urgency is low \\
\hline 3 & IF numcar is verysmall and red times medium then urgency is low \\
\hline 4 & IF numcar is verysmall and red times is long then urgency is low \\
\hline 5 & IF numcar is verysmall and red times is very long then urgency is low \\
\hline 7 & IF numcar is small and red times is very short then urgency is low \\
\hline 8 & IF numcar is small and red times is medium then urgency is medium \\
\hline 9 & IF numcar is small and red times is long then urgency is medium \\
\hline 10 & IF numcar is small and red times is very long then urgency medium \\
\hline 11 & IF numcar is medium and red times is very short then urgency is medium
\end{tabular}

After the rules are found the next step is to apply them to the program that will be created so that the application can be created and run as it should.

\section{CONCLUTION}

The conclusion of this study, that the Mamdani fuzzy method can solve the problem that there is further research after getting a fuzzy mandani rule base is to apply it into the application program so that the program can be run as it should and as expected. 


\section{REFERENCE}

[1] H. Prasetyo and U. Sutisna, "Techno , ISSN 1410 - 8607 IMPLEMENTASI ALGORITMA LOGIKA FUZZY UNTUK SISTEM PENGATURAN Implementation of Fuzzy Logic Algorithm for Traffic Lights Control System Using,” vol. 15, no. 2, pp. 1-8, 2014.

[2] J. Ismail, F. Marisa, and I. D. Wijaya, "Aplikasi Pengenalan Rambu Lalu Lintas Menggunakan Metode Fuzzy Mamdani Berbasis Android," JOINTECS (Journal Inf. Technol. Comput. Sci., vol. 1, no. 1, pp. 33-39, 2016, doi: 10.31328/jointecs.v1i1.406.

[3] E. E. Prasetiyo, O. Wahyunggoro, and S. Sulistyo, "Desain Pengatur Lampu Lalu Lintas Adaptif dengan Kendali Logika Fuzzy," Semin. Nas. Teknol. Inf. dan Multimed. 2015 STMIK AMIKOM Yogyakarta, 6-8 Februari 2015, pp. 6-8, 2015.

[4] M. Maslim, B. Y. Dwiandiyanta, and N. Viany Susilo, "Implementasi Metode Logika Fuzzy dalam Pembangunan Sistem Optimalisasi Lampu Lalu Lintas," J. Buana Inform., vol. 9, no. 1, pp. 11-20, 2018, doi: 10.24002/jbi.v9i1.1661.

[5] R. P. Prasetya, "Implementasi Fuzzy Mamdani Pada Lampu Lalu Lintas Secara Adaptif Untuk Meminimalkan Waktu Tunggu Pengguna Jalan," J. Mnemon., vol. 3, no. 1, pp. 24-29, 2020, doi: 10.36040/mnemonic.v3i1.2526.

[6] P. Juniana and L. Hakim, "Kendali Lampu Lalu Lintas Dengan Menggunakan Metode Fuzzy Logic Mamdani,” J. Terap. Teknol. Inf., vol. 3, no. 1, pp. 1-10, 2019, doi: 10.21460/jutei.2018.31.126.

[7] R. Yusuf, A. Andriansyah, F. Pratiwi, J. T. Elektro, F. T. Industri, and U. M. Buana, "Simulasi Pengaturan Lalu Lintas Menggunakan Logika Fuzzy," pp. 221-226, 2010.

[8] R. A. T. Aufik et al., "Rancang Bangun Simulator Kendali Lampu Lalu Lintas Dengan Logika Fuzzy,” Seminar, vol. 2008, no. RAHMAT TAUFIK, pp. 1-26, 2008.

[9] S. C. Sumarta, P. Studi, T. Informatika, F. T. Informasi, U. Atma, and J. Makassar, "LOGIKA FUZZY METODE MAMDANI PADA BERBAGAI," 1965.

[10] E. E. Prasetiyo, "Perbandingan Kinerja Pengendali Lampu Lalu Lintas Metode Fuzzy Tipe Sugeno Dengan," pp. 6-7, 2016.

[11] S. Nurhayati and I. Immanudin, "Penerapan Logika Fuzzy Mamdani Untuk Prediksi Pengadaan Peralatan Rumah Tangga Rumah Sakit," Komputika J. Sist. Komput., vol. 8, no. 2, pp. 81-87, 2019, doi: 10.34010/komputika.v8i2.2254.

[12] R. Megasari and K. Novianingsih, "Optimisasi Delay Lampu Hijau Dengan Logika Fuzzy Metode," Eureka Matika, vol. 5, no. 2, 2017.

[13] L. Wahyu W, Rakhmat, Afriyanti, "Aplikasi Fuzzy Inference System ( Fis ) Metode Tsukamoto Pada Simulasi Traffic Light Menggunakan Java," Program, vol. 2009, no. 
Snati, pp. 104-107, 2009.

[14] F. Pascasarjana, P. Studi, and S. Informasi, "Pemodelan sistem pendukung keputusan untuk menentukan rute tercepat menggunakan metode fuzzy," pp. 1-12. 